\title{
Future strategies to improve short- and long-term outcomes of renal transplantation in dogs
}

\author{
Larissa Ayane do Nascimento Braz ${ }^{1,3^{*}}$ Suellen Rodrigues Maia ${ }^{2}$ Luciano Alves Faria ${ }^{3}$ iD \\ Alef Winter Oliveira Alvarenga ${ }^{3}$ André Luiz Sampaio Fernandes ${ }^{3}$ (D) \\ Guilherme Lages Savassi Rocha $^{4}$ Leandro Zuccolotto Crivellenti ${ }^{5}$ iD
}

\footnotetext{
${ }^{1}$ Departamento de Clínica e Cirurgia Veterinária, Universidade Estadual Paulista (UNESP), 14884-900, Jaboticabal, SP, Brasil. E-mail: larissa-ayane@hotmail.com. "Corresponding author.

${ }^{2}$ Departamento de Clínica Veterinária, Universidade Estadual Paulista (UNESP), Botucatu, SP, Brasil.

${ }^{3}$ Programa de Pós-graduação em Ciência Animal, Universidade de Franca (UNIFRAN), Franca, SP, Brasil.

${ }^{4}$ Departamento de Medicina Veterinária, Pontifícia Universidade Católica de Minas Gerais (PUC Minas), Belo Horizonte, MG, Brasil.

${ }^{5}$ Programa de Pós-graduação em Ciências Veterinárias Universidade Federal de Uberlândia (UFU), Uberlândia, MG, Brazil.
}

ABSTRACT: Transplants for cats with naturally occurring renal disease have been introduced into clinical practice, but canine renal transplantation represents a greater challenge because of the lack of a balanced immunosuppressive protocol, difficulty in selecting compatible canine kidney donors, and absence of transplantation monitoring protocols. This and other important factors will be discussed in this review to help improve short- and long-term outcomes for renal transplantation in dogs.

Key words: renal replacement therapy, immunosupression, veterinary medicine.

Estratégias futuras para melhorar os resultados de transplante renal em cães a curto e longo prazo

RESUMO: O transplante renal em gatos com doença renal naturalmente adquirida está cada vez mais sendo introduzido na prática clínica. O transplante renal em cães, por sua vez, representa um desafio maior devido a falta da definição de um protocolo imunossupressor equilibrado, dificuldade na seleção de doadores compatíveis e ausência de protocolos de monitoramento de transplantes. Esses e outros fatores serão abordados nesta revisão afim de melhorar os resultados, tanto a curto quanto a longo prazo do transplante renal em cães.

Palavras-chave: terapia de substituição renal, imunossupressão, medicina veterinária.

\section{INTRODUCTION}

Renal failure is a common disease in dogs, humans, and cats, which may result from genetic, toxic, infectious, malignant, vascular, and degenerative causes (URIE, 2007). Although medical management may be initially effective in stabilizing a patient, it is not sufficient to maintain a patient with end-stage renal disease (ESRD) (ARONSON, 2016). Kidney transplantation, which is an established treatment for human patients, is now considered the treatment of choice in cats since it offers prolonged survival and improved quality of life compared to medical management and dialysis (ADIN, 2011; TATAPUDI \& MONTGOMERY, 2017).
Kidney transplantation has been less successful in canine patients, which have higher morbidity and mortality rates than human and feline patients (BROADDUS, 2006; HOPPER, 2012; ARONSON, 2016). The exact reasons for this discrepancy remain undefined, but the intense host immune response of canines has been suggested as the principal cause by several studies (MATHEWS et al., 2000; GREGORY et al., 2006).

Organ rejection episodes in dogs are frequent and severe, making it necessary to use potent multiple-agent immunosuppressive protocols and intensive management strategies to prevent rejection and decrease the likelihood of adverse effects in canine recipients (MATHEWS et al., 2000; GREGORY et al., 2006; PRESSLER, 2010). 
This review article thoroughly discusses future approaches for the medical management, screening, and selection of compatible canine kidney donors, and the need for a balanced immunosuppressive protocol for renal transplantation in dogs.

\section{Host immune response in dogs}

In general, renal rejection after transplantation occurs as a result of an interaction between immunological processes that maintain allograft rejection versus graft tolerance (McDANIEL et al., 2013). The current concepts of transplantation immunology are hinged upon the characterization of the cell surface proteins encoded by major histocompatibility complex (MHC) genes(ADIN, 2011); these proteins are responsible for the presentation of self and non-self antigen repertoires to the immune system-activating T-cells (AYALA GARCÍA et al. 2012; BUENTJEN et al., 2015). In transplantion cases, MHC is considered important because the principal targets of the immune response are the MHC molecules expressed on the surface of donor cells, which causes graft rejection (AYALA GARCÍA et al. 2012). Pharmacologic interventions that reduce T-cell and B-cell activation can prevent allograft rejection (ADIN, 2011; SHIN et al., 2019).

MHC has now been characterized in several species, especially mammals, and are given specific names, such as dog leukocyte antigen (DLA), feline leukocyte antigen (FLA), and the human leukocyte antigen (HLA) (ADIN, 2011; BUENTJEN et al., 2015).

Four discrete DLA genes have been identified in dogs (DLA-12, -88, -79, and -64) and each dog has a total of eight genes (four from each parent), making the level of genetic diversity quite high (ADIN, 2011; MIYAMAE et al., 2018). For these reasons, most efforts at transplantation in dogs with naturally occurring renal disease have been focused on achieving successful immunosuppression in nontissue-matched renal transplant recipients.

\section{Immunosuppression}

The recipient of a kidney transplant requires immune system suppression for the rest of their life; so the common goal of dog transplant strategies is preventing allograft rejection with minimal drug nephrotoxicity and reducing the cost of immunosupression (ADIN, 2006, ADIN, 2011). These strategies have included dose reduction and combination with other drugs. Many drugs have been described in the literature, such as calcineurin inhibitors
(CNIs, i.e. tacrolimus, cyclosporine), antiproliferative agents (i.e., azatioprine, mycophenolate mofetil), prednisone, and combinations thereof (ADIN, 2006; GREGORY et al., 2006; MATHEWS et al., 2000; PHILLIPS \& ARONSON, 2012).

Over the past three decades, a classic combination of drugs has been applied in human beings that includes a glucocorticoid, a CNI, and an antimetabolite, and is therefore typically called "triple drug therapy" (GREGORY, 2006). In more recent years, other nonpharmacologic means have been tested, including monoclonal antibody therapies and nonmyeloblative irradiation (ADIN, 2011).

The use of new combinations of immunosuppressive drugs has decreased the incidence of graft rejections of renal transplants in canine patients. Survival up to seven years has been reported in outbred research dogs with unrelated renal allografts (MATHEWS et al., 2000), but no study in a large population has compared different immunosuppressive drug regimens in the veterinary field.

\section{Induction and maintenance agents}

For induction therapy, antibodies (antithymocyte globulins) or interleukin 2 receptor antagonists (basiliximab) are typically used in humans immediately post-transplant, when immunosuppression is initiated at high levels, because the risk of graft rejection is greatest during this period (DENTON et al., 1999). In pediatric patients undergoing heart transplants, the use of anti-thymocyte globulin for induction therapy is associated with a decreased risk of mortality, when compared with basiliximab (ANSARI et al., 2015). No such study was performed in dogs.

Five drug classes are most commonly used for maintenance regimens, including CNIs (cyclosporine and tacrolimus), mTOR inhibitors (sirolimus and everolimus), antiproliferative agents (azathioprine and mycophenolic acid), costimulation blockers (belatacept), and corticosteroids (HARDINGER \& BRENNAN, 2013).

Glucocorticoids (GCs) are adrenal steroids secreted during stress that exhibit both antiinflamatory and immunomodulatory effects, mediated through inhibition of arachidonic acid metabolism by phospholipase A (TIZARD, 2004; ADIN, 2011).

Corticosteroid receptor complexes stimulate the synthesis of $1 \mathrm{~KB} \alpha$, a protein that inhibits the transcription NF-к $\beta$, essentially halting the generation of a variety of chemoattractants and pro-inflammatory molecules (TIZARD, 2004), including the suppression of IL-2, IL-6, TNF- $\alpha$, 
interferon- $\gamma$, COX-2, and prostaglandins, and inhibition of monocyte migration and lymphocite proliferation (RAY \& SEHGAL, 1992; SORRELLS “\& SAPOLSKY, 2007; ADIN, 2011). Moreover, at a molecular level, GCs inhibit MHC II expression which reduces the $\mathrm{T}$ lymphocyte capacity (SORRELLS \& SAPOLSKY, 2007).

A variety of serious and frequent side effects is associated with steroid therapy in human and dog recipients, including Cushing's syndrome, osteoporosis, adrenal suppression, hyperglycemia, dyslipidemia, cardiovascular disease, and psychiatric disturbances (LIU et al. 2013). Steroid-sparing protocols are typically used in dogs, with initial doses of $10 \mathrm{mg} / \mathrm{kg}$ methylprednisolone at the time of surgery, followed by $1 \mathrm{mg} / \mathrm{kg}$ oral prednisolone per day (MATHEWS et al. 2000; GREGORY et al. 2006), cyclosporine (Neoral; $10 \mathrm{mg} / \mathrm{kg}$ PO q12h), and azathioprine $(2-3 \mathrm{mg} / \mathrm{kg}$ PO q48h). Steroid dosage is halved monthly, then tapered after 3 months (GREGORY et al. 2006). Cyclosporine treatment is continued throughout the recipient's lifetime.

Cats, however, are far more tolerant to chronic glucocorticoid therapy (ADIN, 2011). For this reason, the immunosuppressive protocol currently used for cats consists of the CNI cyclosporine in combination with prednisolone (ARONSON, 2011; ARONSON, 2016). At the same time, steroid-free protocols have been the major focus for treating human and dog transplant recipients.

At present, Cyclosporine, a cyclic polypeptide of fungal origin, appears to be the most effective and widely used immunosuppressive agent for organ transplantationin dogs (KATAYAMA et al., 2010). However, this drug may cause renal toxicity when used for a long-term, as seen in humans (RUSH, 2013).

For this reason, other immunosuppressive drugs have also been tested in veterinary studies. Treatment with a micro-emulsified cyclosporine solution has been used instead of standard commercial cyclosporine (CsA) formulations to decrease adverse effects (BERNSTEEN et al., 2003), and although no studies have compared both drugs side by side, microemulsified cyclosporine appears to have better results than CsA. The dose usually used is $5-20 \mathrm{mg} / \mathrm{kg}$, PO every 12 hours (BERNSTEEN et al., 2003, PHILLIPS \& ARONSON, 2012), but this drug is generally used in combination with other immunosuppressive drugs. Beyond CsA dose, nowadays, whole-blood cyclosporine concentrations should be measured to adjust dosage and maintain a trough concentration, but different maintenance reference limits of blood cyclosporine concentrations for dogs are reported in the literature. This variation is wide, with various studies recommending 200-300 ng/mL (PHILLIPS \& ARONSON, 2012), 400-500 ng/mL (BERNSTEEN et al., 2003), and 400-600 ng/ mL (KATAYAMA et al., 2010), whereas no study has examined the lowest effective dosage.

To reduce the cost of post-transplant immunosuppression, antifungal medications can be used to delay the metabolic clearance of cyclosporine. Veterinary studies have investigated the possibility of decreasing in CsA dosage when used in combination with fluconazole, itraconazole, or ketoconazole (KATAYAMA et al., 2010; ADIN, 2011; ARONSON, 2016); however, more studies about drug interactions, hepatotoxicity, and nephrotoxicity in the long term are required.

Tacrolimus (TAC) or FK506, a macrolide antibiotic compound isolated from Streptomyces tsukubaensis, was the second CNI to be developed. TAC has been shown to be a more potent immunossupressant than CsA, and has been associated with less subclinical inflammation, lower impact on lipid profiles, and less severe interstitial fibrosis than that observed with the use of CsA in humans (RUSH, 2013; HARDINGER \& BRENNAN, 2013; HAN et al., 2017). Tacrolimus-based regimens are now used in more than $95 \%$ of kidney transplant recipients in human medicine (MATAS et al., 2015).

A third CNI, voclosporin, is currently undergoing clinical trials in medicine and appears to be as efficacious as TAC, and is associated with a lower risk of complications (RUSH, 2013); however, no veterinary study has yet used voclosporin.

In one study, mycophenolate mofetil (MMF) was substituted for azatioprine in combination with CsA, and independent of whether MMF is used in combination with CsA-Sandimmune, CsA-Neoral, or Tac, MMF was able to reduce acute rejections (KNIGHT et al., 2009). However, some primary side effects have been reported in dogs treated with oral MMF, such as diarrhea and weight loss (CHANDA et al., 2002). Mild allergic reactions have been reported upon the administration of parenteral MMF in dogs (DEWEY et al., 2001).

Azathioprine, a purine synthesis inhibitor, is an antiproliferative agent that is relatively specific for T-cell and B-cell proliferation (ADIN, 2011), has a delayed onset of action and may require administration for up to $2-5$ weeks or more to be fully effective in dogs (reportedly 3-4 months in humans). Consequently, azathioprine may not be an ideal choice for patients that need acute imunosupression (BEALE, 1988; SEGEV, 2013). 
A "triple therapy" with cyclosporine, azathioprine, and prednisone was tested in 15 dogs; however, it resulted in an unacceptable level of infections and other drug-related complications resulting from an excessive degree of immunosuppression (GREGORY et al., 2006).

Other studies investigating transient immunosuppression with mycophenolate mofetil (5$10 \mathrm{mg} / \mathrm{kg}$ every 12 hours), cyclosporine $(15 \mathrm{mg} / \mathrm{kg}$ every 12 hours), and intermittent prednisone $(1 \mathrm{mg} /$ kg every 12-24 hours), found that when initiated early at lower dosages, this combination may potentially eliminate renal allograft injury (BROADDUS et al., 2006). While a standard dose schedule may be planned, doses of each of the medications can be reduced based on the individual patient's renal function, serum concentrations, and signs of infection or drug toxicity (MATHEWS et al., 2000).

A consensus recommendation for the use of immunosuppressive therapy in dogs with active glomerular diseases (SEGEV, 2013), which probably could be extrapolated for renal transplantation, recommends administering mycophenolate or chlorambucil alone, or in combination with azathioprine on alternating days for stable or slowly progressive glomerular diseases. For dogs with severe, persistent, or progressive glomerular disease, they recommend mycophenolate alone or in combination with prednisolone, if there is evidence of an active immune-mediated pathogenesis by kidney biopsy and no identified contraindication to what should be tapered urgently. A new consensus for renal transplantion may be necessary.

An area of growing research interest in human transplantation is the use of therapeutic strategies such as autologous mesenchymal stem cells (MSC), bone marrow transplantation, emerging drugs/ compounds to target $\mathrm{T}$ cells, alloantibody-producing $\mathrm{B}$ cells, plasma cells, and complements (BROADDUS et al., 2006; ARONSON, 2016; SHIN et al., 2019) to prevent and treat kidney allograft rejection, decrease the risk of neoplasia or opportunistic infections, and improve long-term outcomes.

Autogenous MSC are adult-derived multipotent stem cells and they have an important characteristic of unlimited replication and high ability in differentiation (BOCHON et al., 2019). They seem to be a good option listed as a potential mode of renal reparative and replacement therapy, and also holds a great promise for immune inflammatory processes management in human and more recently in veterinary medicine (YEO \& ZHANG, 2018; BRASILE, STUBENITSKY, 2019). Beside their capabilities of initiating tissue regeneration, MSCs are primary used in transplantations because of their ability to modulate immune responses, which may increase the effectiveness of pharmacological prophylaxis of the transplant rejection (BOCHON et al., 2019).

In pilots studies, MSC has been shown to improve allograft function, reduction in adverse events, and reduction of immunosuppression medications. For example, an human pilot study showed how the infusion of donor-derived bone marrow MSC into graft renal artery during reperfusion and more one month of this infusion intravenously in six recipients. This procedure reduced approximately $50 \%$ of tracolimus dosage used and also no episodes of rejection was observed after 12 months (PENG et al, 2013; BOCHON et al., 2019). In veterinary there is only studies for reduce inflammatory response, but not for renal transplantation. In vitro study in cats, that used Feline bone marrow-derived MSCs (BMMSCs) and adipose-derived MSCs (AMSCs) resulting in a significantly decrease of the neutrophil reactive oxygen species after cocultured with feline neutrophils (MUMAW et al., 2015). In dogs, in vivo MSCs was performed for cartilage regeneration (SASAKI et al., 2019). Thus, although the use of stem cell therapy has the potential to offer great benefits to the veterinary renal transplant recipient, studies are necessary to confirm this hypothesis.

Until the advent of more targeted and effective, less toxic, and tolerogenic immunotherapies, as determined by favorable risk-benefit analysis, the best strategy in dogs is apparently to customize the current immunosuppressive regimens for the specific immune systems of individuals undergoing kidney transplants,. Many studies are still needed.

With the continual development of new immunosuppressive drugs and the refinement of existing protocols, transplantation options will hopefully increase, particularly in dogs. Thus, highly effective, low-toxicity, and low-cost immunosuppressive agents are urgently needed for patients undergoing kidney transplantation.

\section{Canine kidney recipients}

In humans, multiple factors such as the recipient's age, race, HLA incompatibility, and pre-existing comorbidities influence the outcome of allograft survival (LAND, 2007). Information regarding canine renal transplant recipients is limited, but recipient age has been identified as a factor associated with survival after discharge in both cats and dogs (ARONSON, 2016). A study of 26 dogs that underwent renal transplantation found that for every 
1 -year increase in age, the odds of death by 6 months after surgery increased (HOPPER, 2012).

Beyond pharmacologic intervention, procedures to minimize allograft rejection are necessary. Blood typing and DEA matching have been used, but these procedures generally do not have good results for graft survival. Some authors have suggested that purebred siblings or relatives (MATHEWS et al., 2000; PHILLIPS \& ARONSON, 2012) could be used as tissue donors, but these donors can have similar genetic renal defects. This suggestion is based on the fact that the number of compatible antigens has been correlated to graft survival (ADIN, 2011). For future efforts, histocompatibility should be considered when selecting canine kidney donors. A computer program that crossmatches all data about possible candidates for renal donation and CKD receptors, as well as guidelines to adopt the renal donor, could be an important step.

\section{How to flush the donated kidney?}

Flushing the donated kidney is another complex discussion in medical studies (Lin et al., 2004; Lee et al., 2006; Polyak et al., 2008; LEE \& MANGINO, 2009). In veterinary literature, there is only one study showing that a novel organ perfusion solution improved early kidney graft function and cellular integrity after ischemia/reperfusion (POLYAK et al., 2008) compared with saline $(0.9 \%$ $\mathrm{NaCl})$ solution, that has been used routinely in veterinary renal transplants to flush the renal artery (MATHEWS et al., 2000). Other discoveries using Vasosol (VAS) and University of Wisconsin (UW) solutions have attenuated ischemia-reperfusion damage and had the best post-operative results (POLYAK et al., 2008), followed by ascorbic acid (Lee et al., 2006), 5-aminoimidazole-4-carboxamide$1-\beta$-D-ribonucleoside, (AICAR) and $\mathrm{N}$-acetyl cysteine (NAC) (LIN et al., 2004).

\section{Postoperative monitoring protocols}

One of the most critical problems in transplantation today is the relatively high incidence of delayed graft function (DGF) caused by acute tubular necrosis (ATN) after surgery (HAISHIMA et al., 2002; LIN et al., 2004; POLYAK et al., 2008). It is important to monitor patients carefully through weekly physical examinations and assessments of serum creatinine and urea nitrogen concentrations, Packed Cell Volume (PCV), immunosuppressive drug levels, blood total solids and glucose concentrations, and ultrasonography (USG) for eight weeks after surgery (PHILLIPS \& ARONSON, 2012). This is important for the donors as well. In a study of 14 canine donors, renal, and hematologic variables were normal in dogs up to 2.5 years after unilateral nephrectomy kidney donation (URIE, 2007).

Therapeutic effectiveness should be assessed serially by monitoring changes in proteinuria, renal function, and serum albumin concentration. At least eight weeks of rapid-acting nonsteroidal drug therapy (eg, mycophenolate or azathioprine) should be provided in the absence of overt adverse effects, and 8-12 weeks of slow-acting drug therapy should be provided before altering or abandoning an immunosuppressive trial (Segev, 2013).

Determining how to monitor transplant rejection is another issue in veterinary medicine. Needle core biopsy of the transplanted kidney is one of the most important investigations of renal allograft dysfunction in humans (NICHOLSON et al., 2000; ROGIER et al., 2005). These biopsies can be used to accurately distinguish between acute rejection and CNI-related nephrotoxicity, and also identify other pathologies, including ATN, chronic allograft nephropathy, and recurrent disease. Histologic examination of the renal allograft has also been shown to have a useful role in allowing the safe reduction of immunosuppressive therapy (NICHOLSON et al., 2000). Although it was poorly studied for many years in veterinary medicine (HAISHIMA et al., 2002), the International Veterinary Renal Pathology Initiative with specialties in renal pathology is currently presenting very promising data and may overcome this problem.

A biopsy at one and three months could possibly improve renal function, as was shown in a medical study (KURTKOTI et al., 2008), and all acute rejection episodes (clinical and subclinical) and drug nephrotoxicity would be detected, thus improving short-term renal allograft function. Dogs may have increased benefits from this protocol because many cases exhibit acute rejection in the first months.

\section{Noninvasive biomarkers}

In medicine, human noninvasive biomarkers, like the early expression profile of inflammatory markers, liver fatty acid-binding protein, tissue inhibitor metalloproteinase-2, insulin-like growth factor binding protein 7, chemokine ligand 9, chemokine ligand 2, cystatin $\mathrm{C}$, T-cell immunoglobulin domain, and matrix metalloproteinase-7, are used to assess immune risk and ultimately guide therapeutic decision-making following kidney transplantation (McDANIEL et al., 2013; WANG et al, 2016). No such markers exist yet for canine renal transplantation. 


\section{Complications postoperative}

Commonly reported complications in humans, cats, and dogs include thromboembolic disease; allograft rejection; and infection (bacterial, fungal, or protozoal) of the respiratory tract, central nervous system, nasal cavity, skin, and upper and lower urinary tract (HOPPER et al., 2012). Available published data on transplant survival and the incidence of complications in dogs are limited.

\section{Thromboembolic complication}

Thromboembolic complications are a major cause of death in the immediate postoperative period and effective anticoagulation protocols may greatly improve survival in the future (HOPPER et al., 2012). Renal transplant recipients are prothrombotic as a result of both hypercoagulability and hypofibrinolysis. These abnormalities have been attributed to pre-existing hypercoagulable states, glucocorticoid therapy, CsA therapy, DGF, surgical techniques, and inflammatory responses. Enoxaparin sodium $(0.75 \mathrm{mg} / \mathrm{kg}, \mathrm{SC}$, every 24 hours $)$ or heparin (75 U/kg, IV) administration has been reported to prevent thromboembolic complications (PHILLIPS \& ARONSON, 2012).

\section{CONCLUSION}

Despite novel drugs and drug combinations, consensus on an optimal immunosuppressive regimen is lacking. Renal transplant patients undergoing long-term immunosuppression should visit the veterinarian frequently, protocols based on renal biopsy evaluation are necessary for future studies, and drug-combination studies should be compared. Continued experience with managing both short- and long-term complications, as well as the ability to identify specific risk factors during the perioperative and postoperative period, such as documenting outcome after surgery, identifying the cause of death, and looking for factors associated with postoperative death, will hopefully continue to improve long-term outcomes in canine renal transplant patients.

\section{AUTHORS' CONTRIBUTIONS}

All authors contributed equally for the conception and writing of the manuscript. All authors critically revised the manuscript and approved of the final version.

\section{DECLARATION OF CONFLICTS OF INTERESTS}

There is no conflict of interest between the authors or the participating institutions, and the authors do not have any financial relationships to disclose.

\section{ACKNOWLEDGEMENTS}

Larissa Ayane do Nascimento Braz was financed in part by the Coordenação de Aperfeiçoamento de Pessoal de Nível Superior (CAPES), Brasil - Finance code 88887.339240/2019-00.”

\section{REFERENCES}

ADIN, C.A. Canine renal transplantation: the next steps. Veterinary Surgery, v.35, n.2, p.103-104, 2006. Accessed: May, 08, 2019. doi: 10.1111/j.1532-950X.2006.00120.x.

ADIN, C.A. Renal transplantation. In: BARTGES, J.; POLZIN, D.J. Nephrology and Urology of Small Animals. West Sussex, UK: John Wiley \& Sons Ltd., 2011. Chap. 31. p.306-328.

ANSARI, D. et al. Comparison of basiliximab and anti-Thymocyte Globulin as Induction Therapy in Pediatric Heart Transplantation: A Survival Analysis. Journal of the American Heart Association, v.5, n.1, p.e002790, 2015. Accessed: May, 08, 2019. doi: 10.1161/ JAHA.115.002790.

ARONSON, L.R. et al. Effect of cyclosporine, dexamethasone, and human CTLA4-Ig on production of cytokines in lymphocytes of clinically normal cats and cats undergoing renal transplantation. American Journal of Veterinary Research, v.72, n.4, p.541-549, 2011. Accessed: May, 08, 2019. doi: /10.2460/ajvr.72.4.541.

ARONSON, L.R. Update on the current status of Kidney Transplantation for Chronic Kidney Disease in Animals. Veterinary Clinics: Small Animal Practice, v.46, n.6, p.1193-1218, 2016. Accessed: May, 08, 2019. doi: 10.1016/j.cvsm.2016.06.013.

AYALA GARCÍA, M.A. et al. The major histocompatibility complex in transplantation. Journal of Transplantation, v.2012, 2012. Accessed: May, 08, 2019. doi: 10.1155/2012/842141.

BEALE, K.M. Azathioprine for treatment of immune-mediated diseases of dogs and cats. Journal of the American Veterinary Medical Association, v.192, n.9, p.1316-1318, 1988.

BERNSTEEN, L. et al. Microemulsified cyclosporine-based immunosuppression for the prevention of acute renal allograft rejection in unrelated dogs: Preliminary experimental study. Veterinary Surgery, v.32, n.3, p.213-219, 2003. Accessed: May, 08, 2019. doi: $10.1053 /$ jvet.2003.50027.

BOCHON, Benjamin et al. Mesenchymal Stem Cells-Potential Applications in Kidney Diseases. International journal of molecular sciences, v.20, n.10, p.2462, 2019. Accessed: May, 08, 2019. doi: $10.3390 /$ ijms20102462.

BRASILE, Lauren; STUBENITSKY, Bart. Will cell therapies provide the solution for the shortage of transplantable organs?. Current opinion in organ transplantation, v.24, n.5, p.568-573, 2019. Accessed: May, 08, 2019. doi: 10.1097/ MOT.0000000000000686.

BROADDUS, K.D. et al. Renal allograft histopathology in dog leukocyte antigen mismatched dogs after renal transplantation. Veterinary Surgery, v.35, n.2, p.125-135, 2006. Accessed: May, 08, 2019. doi: 10.1111/j.1532-950X.2006.00123.x.

BUENTJEN, I. et al. Characterisation of major histocompatibility complex class I genes at the fetal-maternal interface of marsupials. 
Immunogenetics, v.67, n.7, p.385-393, 2015. Accessed: May, 08, 2019. doi: $10.1007 / \mathrm{s} 00251-015-0842-5$.

CHANDA, S.M. et al. Comparative gastrointestinal effects of mycophenolate mofetil capsules and enteric-coated tablets of sodium-mycophenolic acid in beagle dogs. Transplantation proceedings, v.34, n.8, p.3387-3392, 2002. Accessed: May, 08, 2019. doi: 10.1016/S0041-1345(02)03601-1.

DENTON, M.D. et al. Immunosuppressive strategies in transplantation. The Lancet, v.353, n.9158, p.1083-1091, 1999. Accessed: May, 08, 2019. doi: 10.1016/S0140-6736(98)07493-5.

GREGORY, C.R. et al. Results of clinical renal transplantation in 15 dogs using triple drug immunosuppressive therapy. Veterinary Surgery, v.35, n.2, p.105-112, 2006. Accessed: May, 08, 2019. doi: 10.1111/j.1532-950X.2006.00121.x.

HAISHIMA, A. et al. Acute vascular and interstitial rejection following renal allograft transplantation in dogs. Journal of Veterinary Medical Science, v.64, n.12, p.1137-1140, 2002. Accessed: May, 08, 2019. doi: 10.1292/jvms.64.1137.

HAN, N. et al. Statin therapy for preventing cardiovascular diseases in patients treated with tacrolimus after kidney transplantation. Therapeutics and Clinical Risk Management, v.13, p.1513, 2017. Accessed: May, 08, 2019. doi: 10.2147/TCRM.S147327.

HARDINGER, K.L. et al. Selection of induction therapy in kidney transplantation. Transplant International, v.26, n.7, p.662-672, 2013. Accessed: May, 08, 2019. doi: 10.1111/tri.12043.

HOPPER, K. et al. Outcome after renal transplantation in 26 dogs. Veterinary Surgery, v.41, n.3, p.316-327, 2012. Accessed: May, 08, 2019. doi: 10.1111/j.1532-950X.2011.00924.x.

KATAYAMA, M. et al. Fluconazole decreases cyclosporine dosage in renal transplanted dogs. Research in Veterinary Science, v.89, n.1, p.124-125, 2010. Accessed: May, 08, 2019. doi: 10.1016/j. rvsc.2009.12.018.

KNIGHT, S.R. et al. Mycophenolate mofetil decreases acute rejection and may improve graft survival in renal transplant recipients when compared with azathioprine: a systematic review. Transplantation, v.87, n.6, p.785-794, 2009. Accessed: May, 08, 2019. doi: 10.1097/TP.0b013e3181952623.

KURTKOTI, J. et al. The utility of 1- and 3-month protocol biopsies on renal allograft function: a randomized controlled study. American Journal of Transplantation, v.8, n.2, p.317-323, 2008. Accessed: May, 08, 2019. doi: 10.1111/j.1600-6143.2007.02049.x.

LAND, W.G. Innate immunity-mediated allograft rejection and strategies to prevent it. Transplantation Proceedings, v.39, n.3, p.667-672, 2007. Accessed: May, 08, 2019. doi: 10.1016/j. transproceed.2007.01.052.

LEE, C.Y.; MANGINO, M.J. Preservation methods for kidney and liver. Organogenesis, v.5, n.3, p.105-112, 2009. doi: 10.4161/ org.5.3.9582.

LEE, J. et al. Attenuation of ischemia-reperfusion injury by ascorbic acid in the canine renal transplantation. Journal of Veterinary Science, v.7, n.4, p.375-379, 2006. Accessed: May, 08, 2019. doi: $10.4142 /$ jvs.2006.7.4.375.
LIN, A. et al. Attenuation of ischemia-reperfusion injury in a canine model of autologous renal transplantation. Transplantation, v.78, n.5, p.654-659, 2004. Accessed: May, 08, 2019. doi: 10.1097/01. tp.0000131664.18670.17.

LIU, D. et al. A practical guide to the monitoring and management of the complications of systemic corticosteroid therapy. Allergy, Asthma \& Clinical Immunology, v.9, n.1, p.30, 2013.

MATAS, A.J. et al. OPTN/SRTR 2013 annual data report: kidney. American Journal of Transplantation, v. 15, n. S2, p. 1-34, 2015. Accessed: May, 08, 2019. doi: 10.1111/ajt.13195.

MATHEWS, K.A. et al. Kidney transplantation in dogs with naturally occurring end-stage renal disease. Journal of the American Animal Hospital Association, v.36, n.4, p.294-301, 2000. Accessed: May, 08, 2019. doi: 10.5326/15473317-36-4-294.

MCDANIEL, D.O. et al. Early expression profile of inflammatory markers and kidney allograft status. Transplantation Proceedings, v.45, n.3, p.1520-1523, 2013. Accessed: May, 08, 2019. doi: 10.1016/j.transproceed.2012.08.027.

MIYAMAE, J. et al. Identification of novel polymorphisms and two distinct haplotype structures in dog leukocyte antigen class I genes: $D L A-88, D L A-12$ and $D L A-64$. Immunogenetics, v.70, n.4, p.237-255, 2018. Accessed: May, 08, 2019. doi: 10.1007/s00251017-1031-5.

MUMAW, Jennifer L. et al. Feline mesenchymal stem cells and supernatant inhibit reactive oxygen species production in cultured feline neutrophils. Research in veterinary science, v.103, p.60-69, 2015. Accessed: May, 08, 2019. doi: 10.1016/j.rvsc.2015.09.010.

NICHOLSON, M.L. et al. A prospective randomized trial of three different sizes of core-cutting needle for renal transplant biopsy. Kidney International, v.58, n. 1, p.390-395, 2000. Accessed: May, 08, 2019. doi: 10.1046/j.1523-1755.2000.00177.x.

PENG, Yanwen et al. Donor-derived mesenchymal stem cells combined with low-dose tacrolimus prevent acute rejection after renal transplantation: a clinical pilot study. Transplantation, v.95, n.1, p.161-168, 2013. Accessed: May, 08, 2019. doi: 10.1097/ TP.0b013e3182754c53.

PHILLIPS, H.; ARONSON, L.R. Use of end-to-side arterial and venous anastomosis techniques for renal transplantation in two dogs. Journal of the American Veterinary Medical Association, v.240, n.3, p.298-303, 2012. Accessed: May, 08, 2019. doi: 10.2460/javma.240.3.298.

PRESSLER, B.M. Transplantation in small animals. Veterinary Clinics: Small Animal Practice, v.40, n.3, p.495-505, 2010. Accessed: May, 08, 2019. doi: 10.1016/j.cvsm.2010.01.005.

POLYAK, M.M.R; GROSCHE, A. Comparison of vasosol and University of Wisconsin solutions on early kidney function after 24 hours of cold ischemia in a canine autotransplantation model. Journal of Surgical Research, v.150, n.2, p.255-260, 2008. Accessed: May, 08, 2019. doi: 10.1016/j.jss.2007.11.727.

ROGIER, E. et al. A novel biological assay to detect the active form of TGF- $\beta$ in urine to monitor renal allograft rejection. Kidney International, v. 68 , n. 4, p. 1875-1883, 2005. doi: 10.1111/j.15231755.2005.00607.x 
RUSH, D. The impact of calcineurin inhibitors on graft survival. Transplantation Reviews, v.27, n.3, p.93-95, 2013. Accessed: May, 08, 2019. doi: 10.1016/j.trre.2013.04.003.

SASAKI, Akari et al. Mesenchymal stem cells for cartilage regeneration in dogs. World journal of stem cells, v.11, n.5, p.254, 2019. Accessed: May, 08, 2019. doi: 10.4252/wjsc.v11.i5.254.

SEGEV, G. et al. Consensus recommendations for immunosuppressive treatment of dogs with glomerular disease based on established pathology. Journal of Veterinary Internal Medicine, v.27, n.S1, 2013. Accessed: May, 08, 2019. doi: 10.1111/jvim. 12228 .

SHIN, H.S. et al. Novel targets of immunosuppression in transplantation. Clinics in Laboratory Medicine, v.39, n.1, p.157169, 2019. doi: 10.1016/j.cll.2018.10.008.

SORRELLS, S.F.; SAPOLSKY, R.M. An inflammatory review of glucocorticoid actions in the CNS. Brain, behavior, and immunity, v.21, n.3, p.259-272, 2007. Accessed: May, 08, 2019. doi: 10.1016/j.bbi.2006.11.006.

TATAPUDI, V.S.; MONTGOMERY, R.A. Pharmacologic complement inhibition in Clinical Transplantation. Current Transplantation Reports, v.4, n.2, p.91-100, 2017.

URIE, B.K. et al. Evaluation of clinical status, renal function, and hematopoietic variables after unilateral nephrectomy in canine kidney donors. Journal of the American Veterinary Medical Association, v.230, n.11, p.1653-1656, 2007. Accessed: May, 08, 2019. doi: $10.2460 /$ javma.230.11.1653.

WANG, H. et al. Urine biomarkers in renal allograft. Journal of Translational Internal Medicine, v.4, n.3, p.109-113, 2016. Accessed: May, 08, 2019. doi: 10.1515/jtim-2016-0032.

YEO, Wee-Song; ZHANG, Yao-Chun. Bioengineering in renal transplantation: technological advances and novel options. Pediatric Nephrology, v.33, n.7, p.1105-1111, 2018. Accessed: May, 08, 2019. doi: 10.1007/s00467-017-3706-4. 